\title{
Methanogenic Degradation of Sodium Benzoate in Profundal Sediments from a Small Eutrophic Lake
}

\author{
By ROBERT SLEAT $\dagger$ AND JOHN P. ROBINSON* \\ Department of Plant Biology and Microbiology, Queen Mary College, University of London, \\ Mile End Road, London E1 4NS, U.K.
}

(Received 22 June 1982)

\begin{abstract}
Enrichments were established to examine the potential of Blelham Tarn profundal sediment to metabolize benzoate to $\mathrm{CH}_{4}$ and $\mathrm{CO}_{2}$. Long 'adaptation' times were required before benzoatedependent $\mathrm{CH}_{4}$ production occurred, though both increased inoculum size and prior methanogenic adaption to aliphatic fatty acids reduced the adaptation time. Benzoate was metabolized according to the stoichiometry: $4 \mathrm{C}_{6} \mathrm{H}_{5} \mathrm{COOH}+18 \mathrm{H}_{2} \mathrm{O} \rightarrow 15 \mathrm{CH}_{4}+13 \mathrm{CO}_{2}$. The optimum temperature for $\mathrm{CH}_{4}$ production from benzoate in the enrichments was $37^{\circ} \mathrm{C}$ irrespective of the enrichment temperature. Methanogenic benzoate degradation was associated with a particulate 'floc' in the enrichments and Methanobacterium soehngenii was tentatively identified as an important constituent of this floc by scanning electron microscopy. Anaerobic benzoate fermentation was observed after $4 \mathrm{~h}$ in undiluted sediment by the use of $\left[{ }^{14} \mathrm{C}\right]$ benzoate, and the temperature optimum for ${ }^{14} \mathrm{C}$-labelled gas formation was $28{ }^{\circ} \mathrm{C}$. The ${ }^{14} \mathrm{CH}_{4}:{ }^{14} \mathrm{CO}_{2}$ ratio indicated that methanogenic fermentation of benzoate was occurring in situ. $\mathrm{CO}_{2}$ became the main gaseous product from $\left[{ }^{14} \mathrm{C}\right]$ benzoate when sulphate was added to sediment, and $20 \mathrm{~mm}$-molybdate reversed this effect. Methanogenesis was slightly inhibited by addition of $20 \mathrm{~mm}$-molybdate. Methanogenic benzoate fermentation in sediments was found to be inhibited by $\mathrm{H}_{2}$.
\end{abstract}

\section{INTRODUCTION}

Methane production from aromatic compounds was observed in 1906 by Soehngen (Evans, 1969). Tarvin \& Buswell (1934) were subsequently able to show that a range of aromatic compounds could be metabolized to $\mathrm{CH}_{4}$ and $\mathrm{CO}_{2}$ with greater than $90 \%$ conversion of the substrates into these gases. The main emphasis in the work published after these two reports was on the elucidation of the biochemical mechanism of the breakdown (see Evans, 1977 for a review). Benzoic acid has been used by most workers as a model aromatic compound and the methanogenic fermentation of benzoate has been demonstrated in sewage digester sludge (Clark \& Fina, 1952; Nottingham \& Hungate, 1969; Ferry \& Wolfe, 1976), rumen fluid (Fina \& Fiskin, 1960; Balba \& Evans, 1977), polluted river mud (Shlomi et al., 1978) and freshwater lake sediment (Kaiser \& Hanselmann, 1982). All of these investigators have used enrichment cultures and have found that a characteristic period of time was required before methane production from benzoate could be detected. This period has been called an 'adaptation' period (Clark \& Fina, 1952), a 'time-lag' (Balba \& Evans, 1977) and an 'acclimation lag' (Healy \& Young, 1979).

The microbiology of the enrichments has not been fully investigated because of their complexity. Ferry \& Wolfe (1976) demonstrated that $\mathrm{CH}_{4}$ production could be uncoupled from benzoate degradation and concluded that a microbial food chain involving several organisms

† Present address: Division of Environmental and Nutritional Sciences, School of Public Health, University of California, Los Angeles, California 90024, U.S.A. 
was responsible for the degradation of benzoate to $\mathrm{CH}_{4}$ and $\mathrm{CO}_{2}$. Attempts to isolate component members of the methanogenic enrichments have concentrated on the $\mathrm{CH}_{4}$ producing organisms. Methanobacterium formicicum and Methanospirillum hungatii were isolated from methanogenic benzoate enrichments by Ferry \& Wolfe (1976) whilst Balba \& Evans (1977) tentatively identified Methanobacterium ruminantium and Methanospirillum hungatii in their enrichments. No acetoclastic methanogens have been isolated from such aromatic-degrading enrichments. Evans (1977) has suggested that the benzene ring is first reduced and then cleaved to aliphatic acids by facultative, Gram-negative bacteria that are readily isolated from methanogenic benzoate-degrading enrichments (Ferry \& Wolfe, 1976; Balba \& Evans, 1977).

Sediment from a small eutrophic lake was examined for the presence of micro-organisms capable of methanogenic fermentation of benzoate. Factors affecting this process were examined with particular reference to 'adaptation' times, temperature, sulphate and $\mathbf{H}_{2}$. Sulphate has been shown to alter the fate of immediate methanogenic precursors in freshwater sediments (Winfrey \& Zeikus, 1977). Little evidence is available for sulphate-dependent aromatic metabolism (Evans, 1977). However, during the course of this work, Widdel (1980) reported the isolation of sulphate reducers able to use benzoic acid as the sole carbon and energy source.

\section{METHODS}

Sampling site. Blelham Tarn is a small, eutrophic lake situated close to Lake Windermere in the English Lake District. It is $0.67 \mathrm{~km}$ long, contains approximately $0.69 \times 10^{6} \mathrm{~m}^{3}$ of water and has a maximum depth of $14.5 \mathrm{~m}$ (Jones \& Simon, $1980 a$ ). The tarn becomes thermally stratified in summer and the hypolimnion is deoxygenated, usually to within $6 \mathrm{~m}$ of the surface (Jones, 1976).

Sampling. Sediment was taken from a depth of $13 \mathrm{~m}$, in the profundal zone (Jones \& Simon, 1980b) using a Jenkins surface corer. Sub-samples were taken by extrusion of the sediment core using the device described by Jones (1976). Samples were stored under $\mathrm{N}_{2}$ in butyl-stoppered $40 \mathrm{ml}$ Bellco roll tubes.

Enrichment procedures. All manipulations, preparation of media and culturing were carried out using the strictly anaerobic techniques described by Hungate (1969). Enrichments were established and maintained in FW medium, which contained the following constituents in distilled water at the indicated concentration $\left(\mathrm{g}^{-1}\right)$ : $\mathrm{NH}_{4} \mathrm{Cl}, 0.75 ; \mathrm{K}_{2} \mathrm{HPO}_{4}, 0.4 ; \mathrm{MgCl}_{2} .6 \mathrm{H}_{2} \mathrm{O}, 0.1 ; \mathrm{Na}_{2} \mathrm{CO}_{3}, 1 \cdot 5 ; \mathrm{Na}_{2} \mathrm{~S} .9 \mathrm{H}_{2} \mathrm{O}, 0 \cdot 25$. Resazurin was added as an oxidation indicator at a final concentration of $0.0001 \%(\mathrm{w} / \mathrm{v})$. The medium was boiled, then cooled under a stream of $\mathrm{O}_{2}$-free $\mathrm{N}_{2}$. The $\mathrm{pH}$ was adjusted to $7 \cdot 2$ and the medium dispensed into $15 \times 150 \mathrm{~mm}$ Bellco anaerobic roll tubes (Arnold Horwell Ltd, Kilburn, U.K.) or $100 \mathrm{ml}$ Wheaton reaction bottles (Chromatography Supplies, Hoylake, Wirral, U.K.) which had been outgassed with $\mathrm{O}_{2}$-free $\mathrm{N}_{2}$. The tubes or bottles were fitted with recessed, butyl black rubber stoppers $\left(40 / 50^{\circ}\right.$ shore hardness). After autoclaving, $\mathrm{Na}_{2} \mathrm{~S}$ was added from sterile anaerobic stock solutions. Carbon sources were added from sterile stock solutions $\left(100 \mathrm{~g}^{-1}\right)$ to give a final concentration of $1 \mathrm{~g}^{-1}$. The final $\mathrm{pH}$ was $7 \cdot 4-7 \cdot 6$. All gases were scrubbed free of residual $\mathrm{O}_{2}$ by passage through a heated column $\left(350^{\circ} \mathrm{C}\right)$ containing acid-washed copper. Enrichment cultures were started by adding a $10 \%(w / v)$ inoculum of sediment (wet weight) to $\mathrm{FW}$ medium using strictly anaerobic techniques throughout. The enrichments were incubated at $28^{\circ} \mathrm{C}$ or $37^{\circ} \mathrm{C}$ vertically and unshaken in the dark (Ferry \& Wolfe, 1976). $\mathrm{CH}_{4}$ production was periodically measured. In the case of benzoate, $10 \%$ of the enrichment volume was replaced once a week.

Enrichment and sediment experiments. The stock enrichment cultures were shaken and $5 \mathrm{ml}$ volumes transferred to sterile anaerobic roll tubes under the appropriate $\mathrm{O}_{2}$-free gas. Additions and transfer of cultures and medium were made by using either $1 \mathrm{ml}$ or $10 \mathrm{ml}$ Brunswick disposable plastic syringes (Sherwood Medical Instruments, Crawley, U.K.) fitted with 23 gauge needles. These were repeatedly flushed with $\mathrm{O}_{2}$-free gas before use. After transfer of the cultures, they were allowed to stand for $48 \mathrm{~h}$ before use. Additions to the cultures, from sterile anaerobic stock solutions, were by injection through the recessed stoppers. Tubes were incubated vertically and unshaken in the dark.

Approximately $5 \mathrm{~g}$ (wet weight) of sediment was placed in roll tubes under the appropriate $\mathrm{O}_{2}$-free gas and preincubated at $28{ }^{\circ} \mathrm{C}$ for $1 \mathrm{~h}$ to remove residual $\mathrm{O}_{2}$. Labelled and unlabelled substrates were prepared under $\mathrm{O}_{2}$ free $\mathrm{N}_{2}$. The total volume of additions to the sediment never exceeded $10 \%$ of the sediment volume and was generally less than $5 \%$. The sediment tubes were vortexed vigorously to ensure a uniform distribution of the added substrates. The roll tubes were then spun on a mechanical tube roller (Hungate, 1969) so that a thin film of sediment coated the inside of the tube. This ensured adequate diffusion of gases between the sediment and gas phase. Comparable results were obtained when unspun samples were used. It was assumed that $\mathrm{H}_{2}$ limitation, caused by exposure of a thin film of sediment to a large gas phase, was unimportant, as methanogenic benzoate fermentation requires a low partial pressure of $\mathrm{H}_{2}$ (Ferry \& Wolfe, 1976). Blelham Tarn sediment is generally considered to be $\mathrm{H}_{2}$ limited (Jones et al., 1982). 
Bacterial isolation and enumeration. Aerobic aromatic degraders were isolated from the enrichments on the following medium, which contained ( $\mathrm{g}^{-1}$ final concentration): carbon source, $1 ; \mathrm{NH}_{4} \mathrm{Cl}, 1 ; \mathrm{MgSO}_{4} .7 \mathrm{H}_{2} \mathrm{O}, 0.5$; $\mathrm{FeCl}_{3}, 0.05 ; \mathrm{CaCl}_{2} .2 \mathrm{H}_{2} \mathrm{O}, 0.005$; and $33 \mathrm{ml}$ of a combined solution of $1 \mathrm{M}-\mathrm{Na}_{2} \mathrm{HPO}_{4}$ and $1 \mathrm{M}-\mathrm{KH}_{2} \mathrm{PO}_{4}(\mathrm{pH} 6.8$ ) per litre of medium. Enumeration of such bacteria was by the most probable number (MPN) method of DiGeronimo et al. (1978). The medium of Stanier et al. (1966) was used to determine denitrifying ability.

The $\mathrm{H}_{2}$-utilizing sulphate reducer was isolated, after suitable enrichment, from sewage sludge using the medium of Badziong et al. (1978). Isolation of component members of the benzoate methanogenic enrichment was attempted using the medium and method of McInerney et al. (1979). Benzoate and butyrate were used as carbon sources. Medium B of Ferry \& Wolfe (1976) was used for acetoclastic methanogen isolation attempts.

Sulphate reducers were enumerated by a dilution through agar roll tubes containing the medium of Postgate (1969).

Analytical methods. Methane was measured with a Pye-Unicam series 104 gas chromatogram fitted with a flame ionization detector. The chromatogram was fitted with a $2 \mathrm{~m}$ coiled glass column ( $4 \mathrm{~mm}$ i.d.), packed with $80-100$ mesh Porasil type B. The carrier gas was $\mathrm{N}_{2}$, at a flow rate of $40 \mathrm{ml} \mathrm{min}^{-1}$, the injection volume was $0.5 \mathrm{ml}$ and the column was operated at ambient temperature. Volatile fatty acids were determined by gas chromatography. A $2 \mathrm{~m}$ coiled glass column, packed with $15 \%$ FFAP on Diatomite (60-80 mesh), was held at $135^{\circ} \mathrm{C}$ whilst the detector and injection port were at $160^{\circ} \mathrm{C} . \mathrm{N}_{2}$ was the carrier gas at $40 \mathrm{ml} \mathrm{min}-1$. The culture fluid was filtered through a $0.22 \mu \mathrm{m}$ filter and pretreated by the addition of $10 \%$ formic acid. Before the start of the run formic acid was injected onto the column to minimize ghosting and tailing. Injection volumes were $1-5 \mu \mathrm{l}$. For benzoate determination the culture was filtered and $100 \mu \mathrm{l}$ dried under a stream of $\mathrm{N}_{2}$. Tri-Sil (Phase Separation Ltd, $100 \mu \mathrm{l}$ ) was then added and allowed to stand for $30 \mathrm{~min}$ at room temperature in a desiccator. The trisilyl derivative was

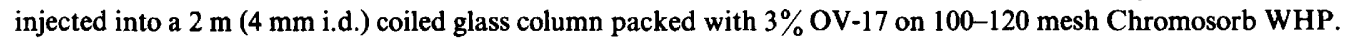
The oven was operated isothermally at $150^{\circ} \mathrm{C}$ and the injection port and detector were at $180^{\circ} \mathrm{C} . \mathrm{N}_{2}$ was the carrier gas at a flow rate of $60 \mathrm{ml} \mathrm{min}^{-1}$ and the injection volumes were 5-20 $\mu \mathrm{l}$.

Radioactive determinations. After incubation with labelled substrate, $1 \mathrm{ml}$ of $1 \mathrm{M}-\mathrm{H}_{3} \mathrm{PO}_{4}$ was injected through the recessed butyl rubber stopper to release dissolved $\mathrm{CO}_{2}$ from the sediment sample or culture fluid. A $0 \cdot 5 \mathrm{ml}$ sample of the gas phase was injected into a stream of air, which was slowly bubbling through $3 \mathrm{ml}$ of Carbo-Sorb (Packard Instrument Co.). A second $0.5 \mathrm{ml}$ was injected into a stream of air and passed through a $1 \mathrm{~cm}$ i.d. silica tube packed with $\mathrm{Cu}$, held at $650-700{ }^{\circ} \mathrm{C}$. The effluent gas was passed into $3 \mathrm{ml}$ of Carbo-Sorb. ${ }^{14} \mathrm{CH}_{4}{ }^{\text {was }}$ combusted to ${ }^{14} \mathrm{CO}_{2}$ which was then trapped in the Carbo-Sorb. The contents of the gas trap were then added to 15 $\mathrm{ml}$ of scintillation fluid and counted in a Packard TriCarb liquid scintillation spectrometer. The scintillation fluid contained the following: $5 \mathrm{~g}$ PPO; $0.1 \mathrm{~g}$ POPOP; 1 litre scintillation-grade toluene. The efficiency of counting was approximately $87 \%$ and samples were corrected for quench by the external channel ratio method. The amount of ${ }^{14} \mathrm{CH}_{4}$ produced was determined from the difference in the counts (total labelled gas released minus ${ }^{14} \mathrm{CO}_{2}$ released). When referred to in the text, ${ }^{14} \mathrm{C}$-labelled gas production refers to both ${ }^{14} \mathrm{CH}_{4}$ and ${ }^{14} \mathrm{CO}_{2}$ produced without prior acidification of the sediment unless specified.

Double-trap experiments showed that all ${ }^{14} \mathrm{CO}_{2}$ was absorbed in the first trap. Comparable results were obtained for ${ }^{14} \mathrm{CH}_{4}$ formation when $\mathrm{NaOH}$ was used as a $\mathrm{CO}_{2}$ trapping agent before passage through the oven. This suggested that ${ }^{14} \mathrm{CH}_{4}$ absorption by Carbo-Sorb was not significant.

Microscopic examination. A Carl-Zeiss photomicroscope was used for phase-contrast observations. For scanning electron microscopy, the cells were fixed in $0.05 \mathrm{M}$-phosphate buffer $(\mathrm{pH} \mathrm{7.2)}$ containing $2 \%(\mathrm{w} / \mathrm{v})$ glutaraldehyde and washed twice in the same buffer. The cells were postfixed in $0.2 \mathrm{M}$-cacodylate buffer ( $\mathrm{pH} 7 \cdot 3$ ) containing $10 \mathrm{~g}$ osmium tetroxide $\mathrm{I}^{-1}$ and washed twice in cacodylate buffer. The cells were dehydrated through a graded series of water/ethanol mixtures. The ethanol was gradually replaced by the non-polar solvent, amyl acetate. Cells were dried from liquid $\mathrm{CO}_{2}$ by critical point drying (Horridge \& Tamm, 1969) and subsequently coated with platinized gold. Scanning electron micrographs were taken with a Jeol JSM-35 scanning electron microscope.

Statistical analysis. $\mathrm{CH}_{4}$ concentrations during adaptation experiments were compared by the Mann-Whitney U-test as described by Jones (1973). $\mathrm{CH}_{4}$ formation rates and ${ }^{14} \mathrm{CH}_{4}:{ }^{14} \mathrm{CO}_{4}$ ratios were compared by the methods described by Harshbarger (1977). Significance levels were calculated by reference to the statistical tables of White et al. (1979).

Chemicals and gases. All chemicals were Analar grade. $\mathrm{N}_{2}(99.9 \%$ was supplied by B.O.C., Hackney, London; $90 \% \mathrm{~N}_{2} / 10 \% \mathrm{H}_{2}$ and $80 \% \mathrm{H}_{2} / 20 \% \mathrm{CO}_{2}$ were supplied by B.O.C. Special Gases, Deer Park Road, London. [ring$\left.\mathrm{U}-{ }^{14} \mathrm{C}\right]$ Benzoate $\left(42 \mathrm{mCi} \mathrm{mmol}^{-1} ; 1.55 \mathrm{GBq} \mathrm{mmol}^{-1}\right)$ was purchased from Amersham.

\section{RESULTS}

When benzoate was added to a $10 \%(\mathrm{w} / \mathrm{v})$ suspension of sediment, methanogenesis was stimulated after 'lag' phases varying from 50 to $80 \mathrm{~d}$. A typical $\mathrm{CH}_{4}$ production profile is shown in Fig. 1. The lag phase, during which $\mathrm{CH}_{4}$ production approximated to that of controls, was 


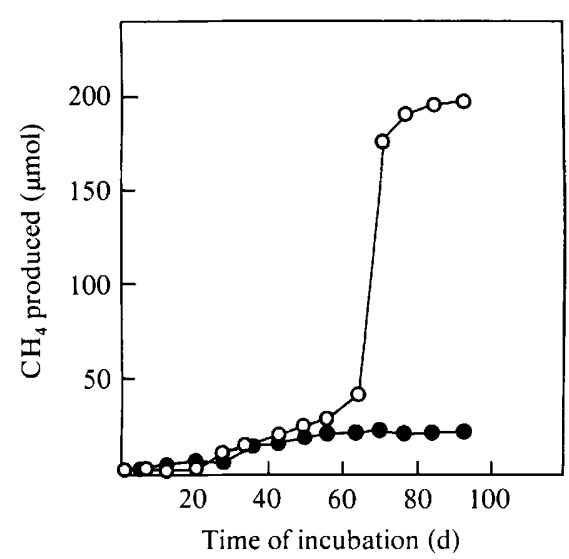

Fig. 1

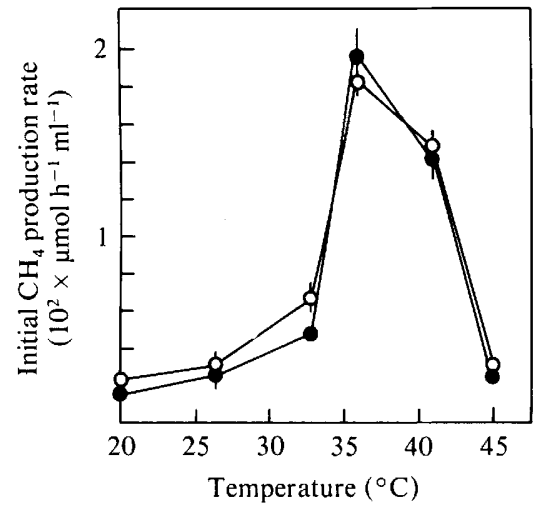

Fig. 2

Fig. 1. $\mathrm{CH}_{4}$ production from benzoate-augmented profundal sediment. Sediment was collected in April 1978; $1 \mathrm{~g}$ wet weight was added to $9 \mathrm{ml}$ of $\mathrm{FW}$ medium containing $1 \mathrm{~g}$ sodium benzoate $\mathrm{l}^{-1}(\mathrm{O})$; identical tubes without benzoate were used as controls $(O)$ and they were all incubated at $37^{\circ} \mathrm{C}$.

Fig. 2. Effect of temperature on the initial rate of $\mathrm{CH}_{4}$ production in enrichments. Benzoate was added to enrichments, established at $37^{\circ} \mathrm{C}(\mathrm{O})$ and $28^{\circ} \mathrm{C}(\mathrm{O})$, to give a final concentration of $5 \mathrm{mM}$. The error bars represent \pm S.E.

Table 1. Comparison of actual and theoretical $\mathrm{CH}_{4}$ production from benzoate by Blelham Tarn enrichments

Samples $(5 \mathrm{ml})$ of enrichment were gassed out with $\mathrm{O}_{2}$-free $\mathrm{N}_{2}$ to remove residual $\mathrm{CH}_{4}$. Benzoate was added to give a final concentration of $5 \mathrm{mM}$ and $\mathrm{CH}_{4}$ measured after $340 \mathrm{~h}$ incubation at $37^{\circ} \mathrm{C}$.

$$
\begin{aligned}
& \mathrm{CH}_{4} \text { production }(\mu \mathrm{mol}) \\
& \overbrace{\text { Theoretical* }^{*} \text { Actual ( } \pm \text { S.D.) }} t \text { score } P \\
& 93.7 \quad 92.5 \pm 2.26 \quad 0.548 \quad>0.6 \\
& \mathrm{C}_{n} \mathrm{H}_{a} \mathrm{O}_{b}+\left(n-\frac{a}{4}-\frac{b}{2}\right) \mathrm{H}_{2} \mathrm{O} \rightarrow\left(\frac{n}{2}-\frac{a}{8}+\frac{b}{4}\right) \mathrm{CO}+\left(\frac{n}{2}+\frac{a}{8}-\frac{b}{4}\right) \mathrm{CH}_{4}
\end{aligned}
$$

followed by a period of rapid methanogenesis. The rate of $\mathrm{CH}_{4}$ production then returned to that found in unaugmented controls. Prior establishment of methanogenic enrichments on a range of aliphatic compounds (acetate, propionate, butyrate, valerate, caproate, heptanoate, adipate and pimelate) decreased the adaptation time required for methanogenic benzoate degradation. Benzoate-dependent methanogenic enrichments were established using sediment samples $\left(100 \mathrm{~g}^{-1}\right)$ from various depths below the sediment-water interface $(4-5 \mathrm{~cm}, 8-9 \mathrm{~cm}, 12-13 \mathrm{~cm}$ and $16-17 \mathrm{~cm}$ ). No methanogenic benzoate enrichments were obtained when sediment from the 0-1 cm depth was used as an inoculum source. Acetate methanogenic enrichments were obtained from all sediment depths tested.

There was no significant difference between the amount of $\mathrm{CH}_{4}$ produced from benzoate added to established enrichments (Table 1) and that calculated from the stoichiometry predicated by the Buswell equation (Buswell \& Muller, 1952). The amount of $\mathrm{CO}_{2}$ produced was assumed to be equal to that predicated by the Buswell equation. The degradation of benzoate to $\mathrm{CH}_{4}$ by established enrichments is consistent with the following stoichiometry calculated from the Buswell equation: $4 \mathrm{C}_{6} \mathrm{H}_{5} \mathrm{COOH}+18 \mathrm{H}_{2} \mathrm{O} \rightarrow 15 \mathrm{CH}_{4}+13 \mathrm{CO}_{2}$. 
A transient accumulation of acetate was detected during $\mathrm{CH}_{4}$ production from benzoate, but propionate, butyrate, caproate and valerate could not be detected. The optimum temperature for $\mathrm{CH}_{4}$ production from benzoate, added to enrichments, was $37^{\circ} \mathrm{C}$ (Fig. 2) irrespective of whether the enrichment was established at $28^{\circ} \mathrm{C}$ or $37^{\circ} \mathrm{C}$. $\mathrm{CH}_{4}$ production was still detectable at $45^{\circ} \mathrm{C}$.

Benzoate metabolism and $\mathrm{CH}_{4}$ production were associated with the particulate fraction in sediment enrichments. No $\mathrm{CH}_{4}$ was produced by supernatant liquor incubated anaerobically with benzoate in the absence of sediment. Little turbidity was observed in the fluid above the sediment during benzoate fermentation.

Weekly removal of $10 \%$ of the enrichment and replacement by FW medium, after shaking, eventually led to the formation of a bacterial 'floc' (Ferry \& Wolfe, 1976). Methanogenic benzoate-degrading activity was associated with this 'floc'. Disruption of the 'floc' by vigorous shaking during incubation with benzoate inhibited $\mathrm{CH}_{4}$ production completely. Benzoate metabolism and $\mathrm{CH}_{4}$ generation were resumed when the 'floc' reformed after the enrichments were allowed to stand unshaken for $48 \mathrm{~h}$.

Bacteria capable of aerobic benzoate and $p$-hydroxybenzoate metabolism were isolated from newly established enrichments at 6.6-7.7 $\times 10^{5}$ per $\mathrm{ml}$ of enrichment. All the isolates were Gram-negative bacilli and possessed nitrate reductase activity. However, no isolate could grow on benzoate or $p$-hydroxybenzoate anaerobically in the presence of nitrate. Such bacteria could not be isolated from enrichments that had been maintained for over 3 years with weekly replacement of $10 \%$ of the enrichment volume.

McInerney et al. (1979) were able to isolate an anaerobic bacterium capable of degrading fatty acids in syntrophic association with $\mathrm{H}_{2}$-utilizing methanogens or sulphate reducers. Similar experiments were attempted to try to isolate benzoate-degrading bacteria in the presence of an $\mathrm{H}_{2}$-utilizing sulphate reducer, isolated from sewage sludge. The methanogenic enrichment was diluted through benzoate/sulphate agar roll tubes containing high numbers of the sulphate reducer. No colonies were observed after 3 months' incubation at $37^{\circ} \mathrm{C}$. Attempts to isolate acetoclastic methanogens from these enrichments were also unsuccessful.

Examination by phase-contrast and electron microscopy revealed the presence of long filaments which ramified throughout the 'floc' and reached lengths greater than $150 \mu \mathrm{m}$. Spiral bundles of filaments were apparent and are believed to give the 'floc' structural integrity (Fig. $3 a$ ). Scanning electron microscopy showed the filaments to be comprised of chains of cells with septa between the cells appearing as prominent bulges (Fig. $3 \mathrm{~b}$ ). Some of the filaments had broken, flattened ends.

\section{Dilution effect}

The initial inoculum size used during the enrichment process directly affected both the time required for the enrichments to produce detectable $\mathrm{CH}_{4}$ from benzoate and adaptation frequency (Fig. 4). Three out of five replicates with a $10 \%(w / v)$ inoculum had not adapted to methanogenic benzoate fermentation after $120 \mathrm{~d}$ incubation. The two replicates that had adapted took 63 and $84 \mathrm{~d}$ respectively for $\mathrm{CH}_{4}$ production to rise above that of controls. No benzoate fermentation was observed for any of the $5 \%(\mathrm{w} / \mathrm{v})$ sediment inoculum samples after $120 \mathrm{~d}$ incubation. In subsequent experiments methanogenic enrichments could be obtained from all sediment depths tested, including $0-1 \mathrm{~cm}$, when a $20 \%(\mathrm{w} / \mathrm{v})$ inoculum size was used.

The observation that increasing inoculum sizes gave decreased adaptation times led us to examine undiluted sediment for the presence of an autochthonous population capable of methanogenic benzoate fermentation without the requirement for an adaptation period. [ring$\left.\mathrm{U}-{ }^{14} \mathrm{C}\right]$ Benzoate was added to undiluted profundal sediment to a final concentration of $4.8 \times$ $10^{-6} \mathrm{mmol}$ ( $\mathrm{g}$ wet $\left.\mathrm{wt}\right)^{-1} \cdot{ }^{14} \mathrm{C}$-labelled gas production was detected after as little as $4 \mathrm{~h}$ anaerobic incubation. The optimum temperature for ${ }^{14} \mathrm{C}$-labelled gas production was about $28{ }^{\circ} \mathrm{C}$ (Fig. 5). Analysis of the labelled gas after acidification of the sediment (Table 2) gave the percentage of ${ }^{14} \mathrm{CH}_{4}$ as $52.3 \pm 5.3$ (mean \pm S.D., 5 determinations), which is consistent with methanogenic fermentation of the [ring-U-14 $\mathrm{C}$ ]benzoate. Labelled gas production was detected when [ring-U- 

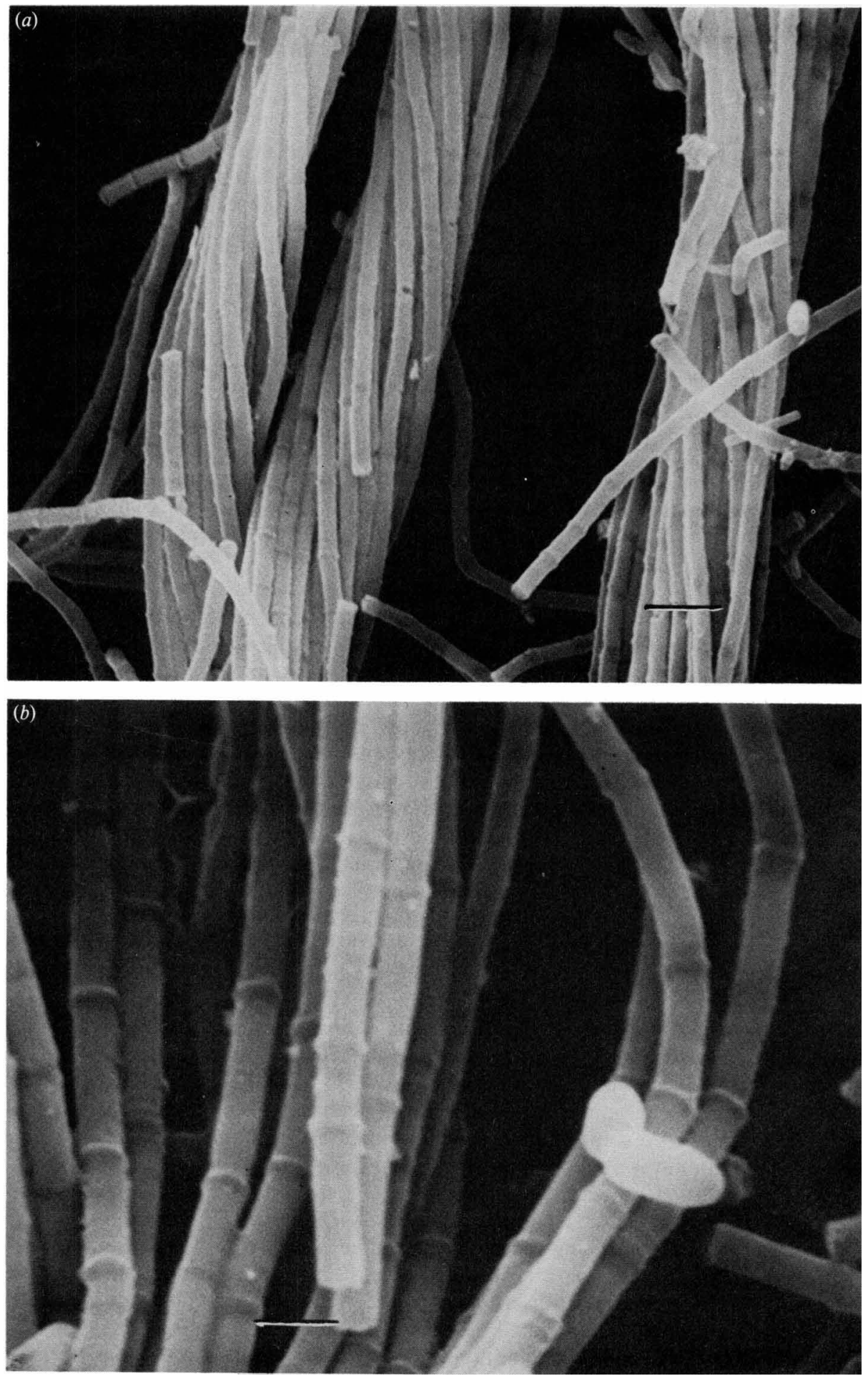

Fig. 3. Scanning electron micrographs of $(a)$ bacterial filament bundles, and (b) bacterial filament bundles with associated bacteria. The bar marker represents $2 \mu \mathrm{m}$ in $(a)$ and $1 \mu \mathrm{m}$ in $(b)$. 


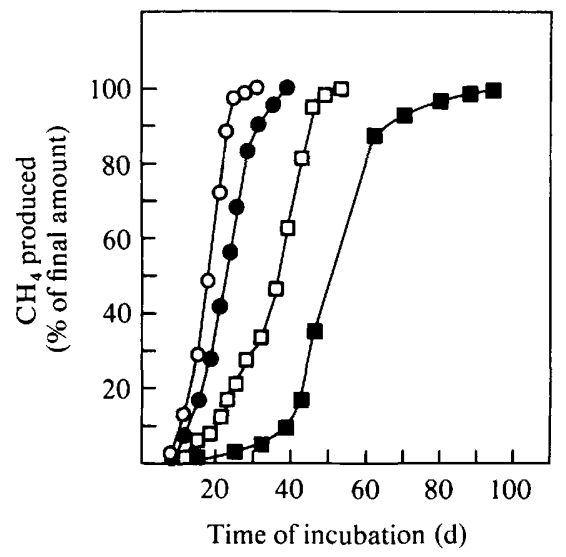

Fig. 4

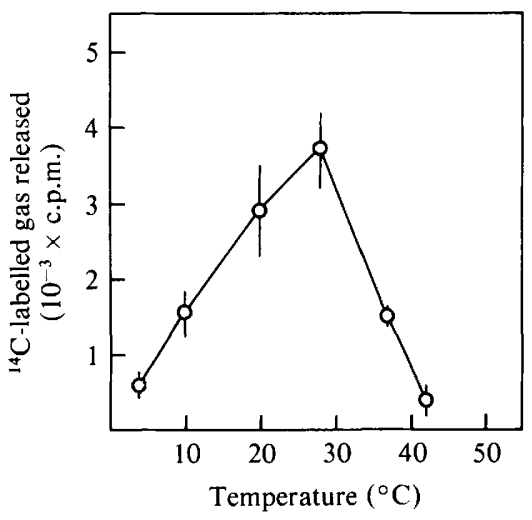

Fig. 5

Fig. 4. $\mathrm{CH}_{4}$ production from benzoate during enrichment establishment with different sediment inoculum sizes. Sediment was collected in September 1979. Benzoate was added ( $5 \mathrm{mM}$ final concentration) to $\mathrm{FW}$ medium containing sediment wet weight concentrations of $50 \%(\mathrm{w} / \mathrm{v})(\mathrm{O}), 40 \%$ (O), $30 \%(\square)$ or $20 \%(\square)$ and the mixture incubated at $28{ }^{\circ} \mathrm{C}$. Each point represents the average of five determinations minus appropriate controls without benzoate.

Fig. 5. Temperature optimum of anaerobic benzoate fermentation by undiluted sediment. Sediment was collected in March 1980 . Sediment $(5 \mathrm{~g})$ and $4 \times 10^{6} \mathrm{c}$.p.m. of [ ring-U-14 C]benzoate were incubated for $20 \mathrm{~h}$ under $\mathrm{O}_{2}$-free $\mathrm{N}_{2}$. The error bars represent \pm S.E.

Table 2. Comparison of $\mathrm{CH}_{4}$ and $\mathrm{CO}_{2}$ produced during $\left[\right.$ ring- $\left.U-{ }^{14} \mathrm{C}\right]$ benzoate fermentation by profundal sediment

Sediment was collected in July 1980 . Samples $(5 \mathrm{~g})$ of sediment were incubated with $1 \mu \mathrm{Ci}$ [ring-U${ }^{14} \mathrm{C}$ ]benzoate under $\mathrm{O}_{2}$-free $\mathrm{N}_{2}$, at $28^{\circ} \mathrm{C}$, for $78 \mathrm{~h}$. The sediment was then acidified and labelled gas determined.

\begin{tabular}{|c|c|c|c|}
\hline \multirow[b]{2}{*}{ Tube } & \multicolumn{2}{|c|}{$\begin{array}{l}\text { Labelled gas produced } \\
\qquad\left(10^{-5} \times \text { c.p.m. }\right)\end{array}$} & \multirow{2}{*}{$\begin{array}{l}\text { Percentage } \\
\text { of } \mathrm{CH}_{4}\end{array}$} \\
\hline & ${ }^{14} \mathrm{CH}_{4}$ & ${ }^{14} \mathrm{CO}_{2}$ & \\
\hline 1 & $2 \cdot 6$ & $2 \cdot 4$ & 52 \\
\hline 2 & $2 \cdot 6$ & 2.9 & 47 \\
\hline 3 & $2 \cdot 8$ & $2 \cdot 7$ & 51 \\
\hline 4 & $3 \cdot 3$ & $2 \cdot 6$ & 55 \\
\hline 5 & $3 \cdot 1$ & $2 \cdot 0$ & 61 \\
\hline
\end{tabular}

${ }^{14} \mathrm{C}$ ]benzoate was incubated under anaerobic conditions with undiluted sediment from all depths including the $0-1 \mathrm{~cm}$ profile.

\section{Effect of sulphate and hydrogen}

Addition of $10 \mathrm{~mm}$-sulphate to stable enrichments affected neither the stoichiometry of the methanogenic benzoate fermentation nor the rate of $\mathrm{CH}_{4}$ formation. Newly adapted enrichments contained about $7 \times 10^{4}$ sulphate-reducing bacteria per $\mathrm{ml}$ of enrichment when determined by MPN counts in lactate medium, whereas similar enrichments maintained for more than 2 years with weekly feeding contained less than 100 sulphate reducing bacteria per $\mathrm{ml}$ of enrichment.

The addition of sulphate ( $10 \mathrm{~mm}$ final concentration) to undiluted sediments containing [ringU-14 C]benzoate did not affect the rate or the amount of ${ }^{14} \mathrm{C}$-labelled gas released (Fig. 6). Sodium molybdate, which has been used as an inhibitor of sulphate reduction in marine 


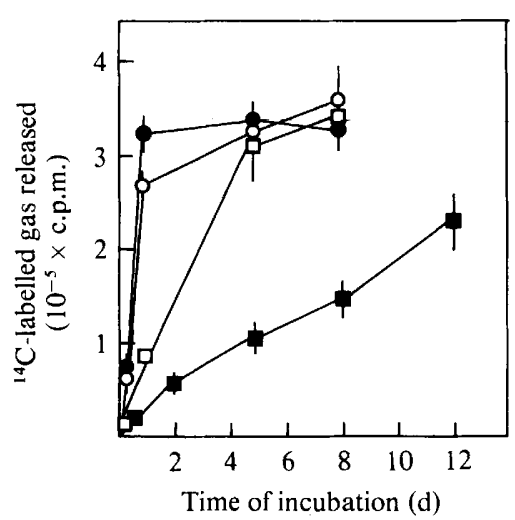

Fig. 6

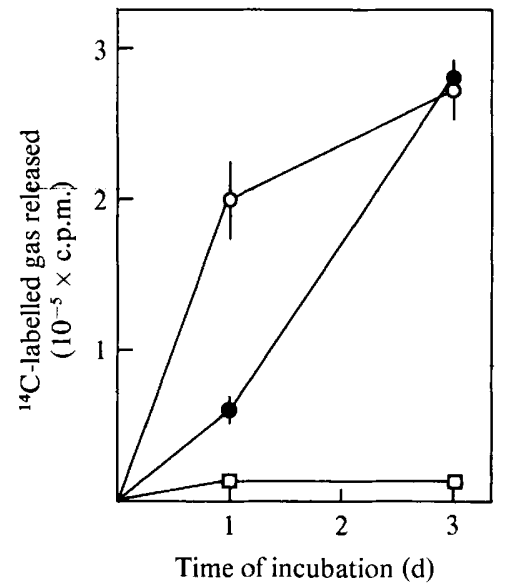

Fig. 7

Fig. 6. Effect of additions of sulphate and molybdate on anaerobic benzoate fermentation by undiluted sediment. Sediment was collected in July 1980 . Sediment samples $(5 \mathrm{~g})$ containing the following additions - none (O), $10 \mathrm{~mm}-\mathrm{SO}_{4}^{2-}(\mathrm{O}), 20 \mathrm{mM}-\mathrm{Na}_{2} \mathrm{MoO}_{4}(\square)$, and $10 \mathrm{~mm}-\mathrm{SO}_{4}^{2-}$ plus $20 \mathrm{mM}-\mathrm{Na}_{2} \mathrm{MoO}_{4}$ (a) - were incubated with $1 \mu \mathrm{Ci}$ of $\left[\right.$ ring-U- $\left.{ }^{14} \mathrm{C}\right]$ benzoate at $28^{\circ} \mathrm{C}$ under $\mathrm{O}_{2}$-free $\mathrm{N}_{2}$. The error bars represent \pm S.E.

Fig. 7. Inhibition of anaerobic benzoate fermentation in sediment by $\mathrm{H}_{2}$. Sediment was collected in July 1980 . Sediment samples $(5 \mathrm{~g})$ were incubated at $28^{\circ} \mathrm{C}$ with $1 \mu \mathrm{Ci}$ of $[$ ring-U-14 $\mathrm{C}]$ benzoate under the following gas atmospheres: $\mathrm{N}_{2}(\mathrm{O}), 90 \% \mathrm{~N}_{2} / 10 \% \mathrm{H}_{2}(\mathrm{O})$ and $100 \% \mathrm{H}_{2}(\square)$. The error bars represent \pm S.E.

Table 3. Comparison of ${ }^{14} \mathrm{CH}_{4}$ and ${ }^{14} \mathrm{CO}_{2}$ produced during metabolism of [ring- $U-{ }^{14} \mathrm{C}$ ]benzoate in the presence of sulphate and molybdate

Sediment was collected in September 1981. Samples $(5 \mathrm{ml})$ of sediment diluted $1: 1(\mathrm{v} / \mathrm{v})$ with anoxic profundal water from Blelham Tarn were incubated under $\mathrm{O}_{2}$-free $\mathrm{N}_{2}$ with $1 \mu \mathrm{Ci}\left[\mathrm{ring}-\mathrm{U}-{ }^{14} \mathrm{C}\right]$ benzoate for $78 \mathrm{~h}$ at $28^{\circ} \mathrm{C}$. Sediment was acidified and labelled gas determined. Each value represents the mean of three tubes.

\begin{tabular}{|c|c|c|c|c|c|c|c|c|c|}
\hline \multirow[b]{3}{*}{ Addition } & \multicolumn{9}{|c|}{ Labelled gas produced $\left(10^{-5} \times\right.$ c.p.m. $)$ and proportion of $\mathrm{CH}_{4}$} \\
\hline & \multicolumn{3}{|c|}{$0-1 \mathrm{~cm}$} & \multicolumn{3}{|c|}{$\begin{array}{l}\text { Depth: } \\
4-5 \mathrm{~cm}\end{array}$} & \multicolumn{3}{|c|}{$11-12 \mathrm{~cm}$} \\
\hline & ${ }^{14} \mathrm{CH}_{4}$ & ${ }^{14} \mathrm{CO}_{2}$ & $\mathrm{CH}_{4}(\%)$ & ${ }^{14} \mathrm{CH}_{4}$ & ${ }^{14} \mathrm{CO}_{2}$ & $\mathrm{CH}_{4}(\%)$ & ${ }^{14} \mathrm{CH}_{4}$ & ${ }^{14} \mathrm{CO}_{2}$ & $\mathrm{CH}_{4}(\%)$ \\
\hline None & 1.8 & $2 \cdot 3$ & 46 & $2 \cdot 7$ & $2 \cdot 0$ & 57 & 2.7 & $2 \cdot 7$ & 50 \\
\hline $20 \mathrm{mM}^{-\mathrm{SO}_{4}^{2-}}$ & $0 \cdot 3$ & 4.9 & 6 & 0.5 & $4 \cdot 2$ & 10 & 0.05 & $4 \cdot 3$ & 1 \\
\hline $20 \mathrm{mM}-\mathrm{MoO}_{4}^{2-}$ & $1 \cdot 4$ & $1 \cdot 0$ & 58 & $3 \cdot 4$ & $1 \cdot 5$ & 69 & 1.9 & 0.9 & 68 \\
\hline $\begin{array}{l}20 \mathrm{mM}-\mathrm{SO}_{4}^{2-}+ \\
20 \mathrm{mM}-\mathrm{MoO}_{4}^{2-}\end{array}$ & $0 \cdot 26$ & 0.53 & 33 & 0.72 & 0.88 & 45 & ND & ND & ND \\
\hline
\end{tabular}

sediments (Oremland \& Taylor, 1978) and freshwater sediments (Smith \& Klug, 1981) was also added to sediments in the presence and absence of sulphate (Fig. 6). At a final concentration of $20 \mathrm{mM}$, molybdate significantly inhibited the release of ${ }^{14} \mathrm{C}$-labelled gas over the first $24-48 \mathrm{~h}$ of incubation. In the presence of added sulphate, molybdate caused a marked inhibition in the rate of ${ }^{14} \mathrm{C}$-labelled gas release throughout the course of the experiment. After $8 \mathrm{~d}$ incubation only $50 \%$ of the control level was produced. This had increased to about $75 \%$ after $12 \mathrm{~d}$ incubation.

The effect of sulphate and molybdate on ${ }^{14} \mathrm{C}$-labelled gas released from [ring-U- $\left.-{ }^{14} \mathrm{C}\right]$ benzoate was further examined by comparing the proportion of ${ }^{14} \mathrm{CH}_{4}$ and ${ }^{14} \mathrm{CO}_{2}$ produced under such conditions (Table 3). In unaugmented sediment approximately equal amounts of ${ }^{14} \mathrm{CH}_{4}$ and 
${ }^{14} \mathrm{CO}_{2}$ were produced during [ring-U- ${ }^{14} \mathrm{C}$ ]benzoate fermentation at all depths examined. Sulphate did not affect the total amount of ${ }^{14} \mathrm{C}$-labelled gas released but it inhibited ${ }^{14} \mathrm{CH}_{4}$ production, most of the label released being ${ }^{14} \mathrm{CO}_{2}$. Molybdate additions to undiluted sediment resulted in much higher proportions of ${ }^{14} \mathrm{CH}_{4}$ compared to ${ }^{14} \mathrm{CO}_{2}$. This appeared to be related to a greater inhibitory effect on ${ }^{14} \mathrm{CO}_{2}$ production than on ${ }^{14} \mathrm{CH}_{4}$. The amount of ${ }^{14} \mathrm{CO}_{2}$ released by the $0-1 \mathrm{~cm}$ depth sample in the presence of molybdate was only $65 \%$ of that released by the control, compared to $77 \%$ for ${ }^{14} \mathrm{CH}_{4}$. The corresponding values for the $11-12 \mathrm{~cm}$ depth sample were $33 \%$ and $70 \%$ respectively. ${ }^{14} \mathrm{CO}_{2}$ production was also inhibited in the $4-5 \mathrm{~cm}$ depth sample when compared to the control, although ${ }^{14} \mathrm{CH}_{4}$ release was apparently stimulated. Addition of both molybdate and sulphate resulted in a significant increase in the proportion of ${ }^{14} \mathrm{CH}_{4}$ produced compared to sulphate alone. The total amount of ${ }^{14} \mathrm{C}$-labelled gas released was greatly decreased in the presence of sulphate and molybdate. This confirms the inhibition of ${ }^{14} \mathrm{C}$-labelled gas release by sulphate plus molybdate shown in Fig. 6.

A $90 \% \mathrm{~N}_{2} / 10 \% \mathrm{H}_{2}$ atmosphere was found to completely inhibit ${ }^{14} \mathrm{CH}_{4}$ production from [ring$\mathrm{U}-{ }^{14} \mathrm{C}$ ]benzoate in established enrichments although during this inhibition methanogenesis from $\mathrm{H}_{2}$ and $\mathrm{CO}_{2}$ could be readily demonstrated in these enrichments. $\mathrm{CH}_{4}$ production occurred quite readily under an $80 \% \mathrm{H}_{2} / 20 \% \mathrm{CO}_{2}$ gas atmosphere although benzoate was not metabolized.

${ }^{14} \mathrm{C}$-labelled gas release from [ring-U-14 $\mathrm{C}$ ]benzoate by undiluted sediment was transiently inhibited by a $90 \% \mathrm{~N}_{2} / 10 \% \mathrm{H}_{2}$ gas atmosphere (Fig. 7) with the amount of ${ }^{14} \mathrm{C}$-labelled gas released being $33 \%$ of that released by the control after $24 \mathrm{~h}$. There was no difference in the amount of ${ }^{14} \mathrm{C}$-labelled gas released after $72 \mathrm{~h}$. A $100 \% \mathrm{H}_{2}$ gas atmosphere completely inhibited ${ }^{14} \mathrm{C}$-labelled gas release.

\section{DISCUSSION}

The methanogenic fermentation of benzoate by Blelham Tarn sediment enrichments was consistent with the stoichiometry first determined by Nottingham \& Hungate (1969) for sewage enrichments. All methanogenic benzoate enrichments subsequently examined produced $\mathrm{CH}_{4}$ and $\mathrm{CO}_{2}$ according to the same stoichiometry (Ferry \& Wolfe, 1976; Balba \& Evans, 1977; Shlomi et al., 1978). It is unlikely that the enrichments studied by different workers were identical in bacterial composition but, as Evans (1977) has pointed out, almost all investigators find the same metabolic intermediates. In the present work only acetate was detected in the culture fluid during $\mathrm{CH}_{4}$ production from benzoate although failure to detect other intermediates may have been due to either their being present at concentrations too low to detect or their being intracellular.

The decrease in 'adaptation' times for methanogenic benzoate fermentation after prior methanogenic 'adaptation' to putative intermediates suggests that the rate of formation of methanogenic precursors by the acetogenic population limits the rate of 'adaptation' in benzoate fermentation. Prior establishment of active acetogenic population ensured the rapid removal of intermediates generated during benzoate metabolism followed by rapid methanogenesis. Ferry \& Wolfe (1976) have calculated that the rapid removal of fermentation intermediates was required for methanogenic benzoate degradation to be thermodynamically favourable. No acetoclastic methanogens were isolated from the enrichments but an organism morphologically similar to Methanobacterium soehngenii (Zehnder et al., 1980) was identified by phase microscopy and scanning electron microscopy (Fig. 3a,b). Methanobacterium soehngenii was isolated by Zehnder and co-workers, after continuous enrichment in a fermenter with a $15 \mathrm{~d}$ retention time, at $33^{\circ} \mathrm{C}$, followed by dilution and growth in liquid medium, and a mean generation time of approximately $9 \mathrm{~d}$ was determined. This slow growth rate may explain the difficulty in isolating this organism from benzoate enrichments. Methanobacterium soehngenii has a substrate affinity for acetate of $0.46 \mathrm{mM}$ (Zehnder et al., 1980) compared to that for Methanosarcina strain 227 of $5 \mathrm{mM}$ (Smith \& Mah, 1980). This may allow Methanobacterium soehngenii to compete with the faster growing Methanosarcina sp. to become the predominant acetoclastic methanogen in such enrichments. Interestingly, the turnover rates of all 
enrichments which have been reported are slow, and long rod-shaped organisms have been observed in these enrichments (Ferry \& Wolfe, 1976; Shlomi et al., 1978; Healy et al., 1980). Cells like Methanobacterium soehngenii formed a matrix in the benzoate enrichments which appeared to give the 'floc' its structural integrity. Within this matrix members of the consortium may form specific spatial relationships with one another. Disruption of the 'floc' by vortexing caused a cessation of $\mathrm{CH}_{4}$ production from benzoate. Whether this was due to its effect on Methanobacterium soehngenii alone or on the proposed spatial relationship is unknown. The maintenance of the structure of the 'floc' appears to be necessary for active methanogenic benzoate fermentation. No evidence was found which indicated that facultative, Gramnegative, aerobic aromatic oxidizers were responsible for anaerobic benzoate degradation in methanogenic enrichments, as had been claimed by Evans (1977).

As might have been expected, dilution of pooled sediment samples was found to increase the 'adaptation' period for methanogenic benzoate fermentation. It was thought that the dilution effect was responsible for the failure to obtain benzoate methanogenic enrichments from the 0-1 $\mathrm{cm}$ depth although methanogenic alicyclic fatty acid enrichments were readily obtained. This was confirmed by using a larger inoculum for enrichments, when benzoate fermentation was shown to occur in the $0-1 \mathrm{~cm}$ sediment depth.

Nottingham \& Hungate (1969) demonstrated decomposition of small concentrations of $\left[{ }^{14} \mathrm{C}\right]$ benzoate to ${ }^{14} \mathrm{CH}_{4}$ and ${ }^{14} \mathrm{CO}_{2}$ at $37{ }^{\circ} \mathrm{C}$ without prior exposure to benzoate by a laboratory methanogenic digester, fed nutrient broth, yeast extract and glucose on a $10 \mathrm{~d}$ retention time. This result suggested the presence of an autochthonous population in the digester capable of anaerobic benzoate fermentation. The results from the experiment on dilution effects similarly suggested the existence of a similar autochthonous population in Blelham Tarn profundal sediment. The release of ${ }^{14} \mathrm{C}$-labelled gas from [ring-U- ${ }^{14} \mathrm{C}$ ]benzoate added to undiluted anaerobic sediment after as little as $4 \mathrm{~h}$ confirmed this. This demonstrates that there is no requirement for population selection during the enrichment process and that adaptation times are probably the result of diluting sediments before establishing enrichments.

The temperature optimum of $28^{\circ} \mathrm{C}$ for in situ benzoate fermentation was in close agreement with that determined for methanogenesis in Blelham Tarn (Jones et al., 1982). Zeikus \& Winfrey (1976) showed that the temperature optimum for the production of ${ }^{14} \mathrm{CH}_{4}$ from $\mathrm{Na}_{2}{ }^{14} \mathrm{CO}_{3}$ in Lake Mendota sediments was $37^{\circ} \mathrm{C}$. Similarly, the optimum temperature for $\mathrm{CH}_{4}$ production from benzoate by Blelham Tarn methanogenic enrichments was found to be about $37^{\circ} \mathrm{C}$. The temperature optimum of $28^{\circ} \mathrm{C}$ determined by Jones et al. (1982) probably reflects the temperature optimum of methanogenic precursor formation, as these sediments are known to be $\mathrm{H}_{2}$ limited (Jones et al., 1982). These workers did not determine the temperature optimum for methanogenesis under conditions of excess substrate or from label studies. If anaerobic benzoate decomposition in sediments was limited by methanogenesis, an optimum temperature of $37^{\circ} \mathrm{C}$ for methanogenic benzoate fermentation would be expected. The temperature optimum of $28^{\circ} \mathrm{C}$ suggests that the limiting step in vivo is either ring cleavage or the production of methanogenic precursors.

The addition of sulphate to sediment altered the fate of carbon derived from [ring-U${ }^{14} \mathrm{C}$ ]benzoate, with $\mathrm{CO}_{2}$ being the predominant fermentation product. This is consistent with inhibition of methanogenesis by added sulphate (Winfrey \& Zeikus, 1977), since sulphatereducing bacteria are then able to compete successfully for the methanogenic precursors, $\mathrm{H}_{2}$ (Winfrey \& Zeikus, 1977; Abram \& Nedwell, 1978) and acetate (Winfrey \& Zeikus, 1977; Laanbroek \& Pfennig, 1981). This does not rule out the possibility that a population of sulphate reducers able to use benzoate as the sole source of carbon and energy in the presence of sulphate (Widdel, 1980) was present in the sediment. Thermodynamic considerations suggest that the removal of $\mathrm{H}_{2}$, generated during anaerobic benzoate metabolism, is necessary for the fermentation to continue (Ferry \& Wolfe, 1976). This is accomplished either by methanogenic bacteria or, in the presence of sulphate, by sulphate-reducing bacteria. Blelham Tarn is sulphate limited (Jones \& Simon, 1980 b) and methanogenic decomposition of benzoate is probably the normal method of benzoate fermentation in anaerobic sediment.

Although molybdate has been used as a specific inhibitor of sulphate reduction (Oremland \& 
Taylor, 1978), recent reports (Smith \& Klug, 1981; Jones et al., 1982) have shown that at concentrations of about $20 \mathrm{~mm}$ methanogenesis is also inhibited. These effects were also observed during this study. ${ }^{14} \mathrm{C}$-labelled gas release (Fig. 6) and ${ }^{14} \mathrm{CH}_{4}$ production were both inhibited in the presence of molybdate. Interestingly, the proportion of ${ }^{14} \mathrm{CH}_{4}$ released, compared to ${ }^{14} \mathrm{CO}_{2}$, increased when molybdate was present. This could be due to the inhibition of ${ }^{14} \mathrm{CO}_{2}$ production by sulphate reducers utilizing a small amount of endogenous sulphate. The major effect of the added molybdate was seen when it was added in conjunction with sulphate. Under such conditions the methanogenic population is able to compete successfully for the methanogenic precursors released during benzoate fermentation, as sulphate reduction is totally inhibited in the presence of molybdate (Smith \& Klug, 1981). The degree of inhibition is related to both the molybdate concentration and the sulphate concentration. Under the conditions used in this study it is doubtful if sulphate reduction was completely inhibited, because of the high sulphate levels used. This would account for the decreased proportion of ${ }^{14} \mathrm{CH}_{4}$ produced compared to the unaugmented control and the addition of molybdate alone.

The inhibition of benzoate fermentation in sediments and enrichments by $\mathrm{H}_{2}$ is consistent with the requirement for low partial pressures of $\mathrm{H}_{2}$ during the metabolism of fatty acids, which are benzoate fermentation intermediates, to acetate, $\mathrm{H}_{2}$ and $\mathrm{CO}_{2}$ (Boone \& Bryant, 1980; McInerney et al., 1979). Benzoate methanogenic enrichments were unable to reduce the $\mathrm{H}_{2}$ concentration below a threshold level at which benzoate fermentation would occur. Profundal sediment is $\mathrm{H}_{2}$ limited (Jones et al., 1982) and small amounts of exogenously added $\mathrm{H}_{2}$ would be quickly consumed allowing the fermentation to proceed. In all experiments where [ring-U${ }^{14} \mathrm{C}$ ]benzoate was added to sediments, only about $30 \%$ of the added label was recovered as labelled gas. Increased incubation times did not increase the amount of label released. The amount of label remaining as $\left[\right.$ ring- $\left.\mathrm{U}-{ }^{14} \mathrm{C}\right]$ benzoate or labelled intermediates was not determined. Incorporation into cell carbon is unlikely, since even in enrichment cultures, added labelled benzoate can be accounted for mainly as ${ }^{14} \mathrm{CH}_{4}$ and ${ }^{14} \mathrm{CO}_{2}$ and residual labelled benzoate, with only traces remaining as cell carbon (Ferry \& Wolfe, 1976). Strayer \& Tiedje (1978) recovered $23-32 \%$ of $\left[2-{ }^{14} \mathrm{C}\right]$ acetate added to Lake Wintergreen sediment as ${ }^{14} \mathrm{CH}_{4}$ and $6 \%$ as ${ }^{14} \mathrm{CO}_{2}$. Similarly $12 \%$ of the $\left[2-{ }^{14} \mathrm{C}\right]$ acetate added to Lake Mendota sediment by Winfrey et al. (1977) was recovered as $\mathrm{CH}_{4}$. The fate of the remaining label in both sediment samples was unknown. Ansbaek \& Blackburn (1980) were able to show greater than $80 \%$ conversion of added $\left[{ }^{14} \mathrm{C}\right]$ acetate to ${ }^{14} \mathrm{CO}_{2}$ by anaerobic marine sediment. They also demonstrated that approximately $3 \%$ of the added label was bound to the sediment, making it unavailable for bacterial uptake. Similar binding or other unidentified reactions, which sequester labelled benzoate or its fermentation intermediates, may account for the proportion of labelled benzoate converted into labelled gases.

R.S. was in receipt of a N.E.R.C. research assistantship. We would like to thank J. G. Jones and B. M. Simon of the Freshwater Biological Association, Windermere, for their help and advice during the sampling of Blelham Tarn, and Mrs. J. Smith who typed the manuscript.

\section{REFERENCES}

ABRAM, J. W. \& NEDWELL, D. B. (1978). Hydrogen as a substrate for methanogenesis and sulphate reduction in anaerobic saltmarsh sediment. Archives of Microbiology 117, 93-97.

ANSBAEK, J. \& Blackburn, T. H. (1980). A method for the analysis of acetate turnover in a coastal marine sediment. Marine Ecology 5, 253-264.

Badziong, W., Thauer, R. K. \& Zeikus, J. G. (1978). Isolation and characterisation of a Desulfovibrio growing on hydrogen plus sulfate as the sole energy source. Archives of Microbiology 116, 41-49.

Balba, M. T. \& Evans, W. C. (1977). The methanogenic fermentation of aromatic compounds. Biochemical Society Transactions 5, 302.
Boone, D. R. \& Bryant, M. P. (1980). Propionatedegrading bacterium, Syntrophobacter wolinii sp. nov. gen. nov., from methanogenic ecosystems. Applied and Environmental Microbiology 40, 626632.

Buswell, A. M. \& Muller, H. F. (1952). Mechanism of methane formation. Industrial and Engineering Chemistry 44, 550-552.

Clark, F. M. \& Fina, L. R. (1952). The anaerobic decomposition of benzoic acid during methane fermentation. Archives of Biochemistry and Biophysics 36, 26-32.

DiGeronimo, M. J., Nikaido, M. \& AleXander, M. (1978). Most probable number techniques for the 
enumeration of aromatic degraders in natural environments. Microbial Ecology 4, 263-266.

Evans, W. C. (1969). Microbial transformations of aromatic compounds. In: Fermentation Advances, pp. 649-687. Edited by D. Perlman. New York: Academic Press.

Evans, W. C. (1977). Biochemistry of the bacterial catabolism of aromatic compounds in anaerobic environments. Nature, London 270, 17-22.

FERRY, J. G. \& WolfE, R. S. (1976). Anaerobic degradation of benzoate to methane by a microbial consortium. Archives of Microbiology 107, 33-40.

FINA, L. R. \& Fiskin, A. M. (1960). Anaerobic decomposition of benzoate during methane fermentation. II. Fates of carbons one and seven. Archives of Biochemistry and Biophysics 91, 163-165.

HARSHBARgER, T. H. (1977). Introductory Statistics. A Decision Map, 2nd edn. London: Collier Macmillan.

HeALY, J. B. \& Young, L. Y. (1979). Anaerobic degradation of eleven aromatic compounds to methane. Applied and Environmental Microbiology 39, 216-218.

Healy, J. B., Young, L. Y. \& Reinhard, M. (1980). Methanogenic decomposition of ferulic acid, a model lignin derivative. Applied and Environmental Microbiology 39, 436-444.

HoRridge, G. A. \& TAMM, S. L. (1969). Critical point drying for scanning electron microscopic study of ciliary motion. Science 163, 817-819.

Hungate, R. E. (1969). A roll tube method for the cultivation of strict anaerobes. Methods in Microbiology 3B, 117-132.

JoNES, J. G. (1973). Use of a nonparametric test for the analysis of data obtained from preliminary surveys: a review. Journal of Applied Bacteriology 36, 197-210.

JoNES, J. G. (1976). The microbiology and decomposition of seston in open water and experimental enclosures in a productive lake. Journal of Ecology 64, 241-278.

JONES, J. G. \& SIMON, B. M. (1980a). Variability in microbiological data from a stratified eutrophic lake. Journal of Applied Bacteriology 49, 127-135.

JoNES, J. G. \& SimoN, B. M. (1980b). Decomposition processes in the profundal region of Blelham Tarn and the Lund tubes. Journal of Ecology 68, 493-512.

JoNes, J. G., Simon, B. M. \& GARDENER, S. (1982). Factors affecting. methanogenesis and associated anaerobic processes in the sediments of a stratified eutrophic lake. Journal of General Microbiology 128, 1-11.

Kaiser, J. P. \& Hanselmann, K. W. (1982). Aromatic chemicals through anaerobic microbial conversion of lignin monomers. Experientia 38, 167-176.

LaAnbroek, H. G. A. \& Pfennig, N. (1981). Oxidation of short-chain fatty acids by sulfate-reducing bacteria in freshwater and in marine sediments. Archives of Microbiology 128, 330-335.
McInerney, M. J., Bryant, M. P. \& Pfennig, N. (1979). Anaerobic bacterium that degrades fatty acids in syntrophic association with methanogens. Archives of Microbiology 122, 129-135.

Nottingham, P. M. \& Hungate, R. E. (1969). Methanogenic fermentation of benzoate. Journal of Bacteriology 98, 1170-1172.

OREMLAND, R. S. \& TAYLOR, B. F. (1978). Sulfate reduction and methanogenesis in marine sediments. Geochimica et cosmochimia acta 43, 209-214.

Postgate, J. R. (1969). Media for sulphur bacteria: some amendments. Laboratory Practice 18, 286.

Shlomi, E. R., Lankhorst, A. \& Prins, R. A. (1978). Methanogenic fermentation of benzoate in an enrichment culture. Microbial Ecology 4, 249-261.

SMITH, M. R. \& MAH, R. A. (1980). Acetate as the sole carbon and energy source for growth of Methanosarcina strain 227. Applied and Environmental Microbiology 39, 993-999.

SMITH, R. L. \& KLUG, M. J. (1981). Electron donors utilised by sulfate-reducing bacteria in eutrophic lake sediments. Applied and Environmental Microbiology 42, 116-121.

Stanier, R. Y., Palleroni, N. J. \& Doudoroff, M. (1966). The aerobic pseudomonads: a taxonomic study. Journal of General Microbiology 43, 159-271.

STRAyeR, R. F. \& TIEdJe, J. M. (1978). Kinetic parameters of the conversion of methane precursors to methane in a hypereutrophic lake sediment. Applied and Environmental Microbiology 36, 330-340.

TARVIN, D. \& Buswell, A. M. (1934). The methane fermentation of organic acids and carbohydrates. Journal of the American Chemical Society 56, 17511755.

White, J., Yeats, A. \& Skipworth, G. (1979). Tables for Statisticians. Cheltenham: Stanley Thornes.

WIDDEL, F. (1980). Anaerober Abbau von Fettsäuren und Benzoesäure durch neu isolierte Arten sulfat-reduzierender Bakterien. Dissertation zur Erlangung des Doktorgrades der Georg-August-Universität zu Göttingen.

Winfrey, M. R. \& ZeIKus, J. G. (1977). Effect of sulfate on carbon and electron flow during microbial methanogenesis in freshwater sediments. Applied and Environmental Microbiology 33, 275-281.

Winfrey, M. R., Nelson, D. R., KLeVICKIS, S. C. \& ZEIKUS, J. G. (1977). Association of hydrogen metabolism with methanogens in Lake Mendota sediments. Applied and Environmental Microbiology 33, 312-318.

ZEHNDER, A. J. B., HUSER, B. A., BROCK, T. D. \& WUHRMANN, K. (1980). Characterisation of acetatedecarboxylating, non-hydrogen-oxidising methane bacterium. Archives of Microbiology 124, 1-11.

ZeIXUS, J. G. \& WinfREY, M. R. (1976). Temperature limitations of methanogenesis in aquatic sediments. Applied and Environmental Microbiology 31, 94-107. 